\title{
THE COMPARISON OF UNESCAP'S CHARACTERISTICS OF GOOD GOVERNANCE AND ISLAMIC CHARACTERISTICS OF GOVERNANCE FOR PUBLIC SERVICES REFORM IN INDONESIA
}

\author{
Wisber Wiryanto \\ National Institute of Public Administration
}

\begin{abstract}
Good governance is a global and sustainable issue. International institutions offer the concept of good governance for bureaucracy and public services reform to various countries. Indonesia is one of the countries that have implemented and developed the concept of good governance.However, the establishment of such structures and regulations, is not a guarantee for improving the effectiveness of good governance implementation. In connection with the above mentioned issues, it is deemed necessary to conduct researc. The reasons of consideration that the majority of Indonesia's population adheres to Islam as great potential toward Islamic governance. This study is conducted to answer the problem formulation, what is similarities and differences between UNESCAP's Characteristics of Good Governance and Islamic Characteristics of Governance? The study used library research method, based on Holy Qur'an and Hadith Nabawi, relevant textbooks and websites, with direct observation in the field. Collecting and analyzing data based on descriptive qualitative method. This study was conducted in Indonesia, in the first half of 2018. Concluded, Islamic characteristics of governance consist of: shari'ah, 'adl, ta'awun, bayan, itqan \& tawazun, shura, at-tabayun and mas'uliyah. There are similarities of categories, and differences the annotation of categories between UNESCAP's characteristics of governance and Islamic Characteristics of Governance. As an implication then government officials must apply Islamic governance and ethics for public service reform in Indonesia.
\end{abstract}

Keywords: Islamic Governance, Good Governance, UNESCAP, Characteristic, Public Services Reform.

*Corresponding author's email: wisberwiryanto@yahoo.com

ISSN: 2549-3221 (Print) 2549-323X (Online)

DOI: $10.26487 /$ hebr.v\%vi\%i.1545 


\section{INTRODUCTION}

In decades, the development of higher eGood governance is a global and sustainable issue. International institutions offer the concept of good governance for bureaucracy and public services reform to various countries. These international agencies include the World Bank (WB), the United Nations Development Program (UNDP), and the United Nations Economic and Social Commission for Asia and the Pacific (UNESCAP). Good governance concepts are offered, among others, characteristics and principles of good governance. Therefore, many countries have applied the concept of good governance. In addition, they also develop the concept of good governance in accordance with the needs.

Indonesia is one of the countries that have implemented and developed the concept of good governance. This is indicated by the establishment of regulations and institutional infrastructure good governance. Law of the Republic of Indonesia no. 28/1999 on the Implementation of the State Clean and Free from KKN, identifies general principles of state administration. In addition, the Decree of the Coordinating Minister for Economic Affairs Ekuin No. KEP/31/M.EKUIN/o8/1999 and Decree of the Coordinating Minister for Economic Affairs No. Kep-49/ M.Ekon/11/2004 on National Committee on Governance Policy (KNKG). Establishment of KNKG to perform its duties and functions related to good governance regulation. KNKG has established policies in the form of general guidance, sectoral guidance and manual of implementing good governance as many as eleven regulations.

However, the establishment of such structures and regulations, is not a guarantee for improving the effectiveness of good governance implementation. The Kaufman et al. in the Aggregating Governance Indicator, Washington DC, World Bank Report 2009, shows a trend of improving good governance Indonesia 1998-2010 in six indicators of control of corruption, political stability and absence of violence, voice accountability, rule of law, regulatory quality and government effectiveness ; while the three indicators, namely rule of law, control of corruption, and political stability are still in bad performance (Ardiansyah, 2017).

To ensure the increased effectiveness of the implementation of good governance, it is necessary to consider the problems and the strategic environment of the country concerned. The reasons are among others: (1) the problem of mismanagement, because the governance for public services applied prefer the ratio of revelation, whereas human reason is not spared from error because it is not guided by revelation as the guidance for happiness of life in the world and the hereafter (Wiryanto, $2016: 8$ ); and (2) the strategic environment of Indonesian demography, based on statistics show that Muslims in Indonesia reached 207,176,162 people or 87.18 percent (Naim \& Saputra, 2011: 10). It means that the majority of Indonesia's population adheres to Islam as great potential toward Islamic governance and ethics for Public Services Reform in Indonesia.

In connection with the above mentioned issues, it is deemed necessary to conduct research under the title of the comparison of UNESCAP's Characteristics of Good Governance and Islamic Characteristics of Governance for Public Services Reform in Indonesia. This research is conducted to answer the problem formulation, consist of: (1) What is the similarities and differences between UNESCAP's Characteristics of Good Governance and Islamic Characteristics of Governance? (2) What 
is Islamic characteristicts of governance?

This study aims to determine the similarities and differences between UNESCAP's Characteristics of Good Governance and Islamic Characteristics of Governance. Furthermore, the expected output of this study, so that the results of this study can be used by the government for input materials for public services reforms in Indonesia. On the other hand, for Muslims in Indonesia to understand the characteristics of Islamic governance outlined in the Qur'an and Al-Hadith, so that public services can be well organized for the welfare of the community.

\section{LITERATURE REVIEW}

Literature review contains description of good governance both general and specific, which include, among others, UNESCAP'S characteristics of good governance; Islamic charactersistics of governance; and related studies on Islamic governance, as described below.

\subsection{UNESCAP's Characteristics of Good Governance}

Good Governance consists of words Good and Governance. The term governance means not only the governance of an activity, but also means management, direction, coaching and organization. Governance consists of three components namely public governance refers to government institutions, corporate governance refers to the private sector / business world, and civil society.

Characteristics of good governance can be studied from various concepts developed by international institutions, as already mentioned. Among the international institutions are not all call it as a characteristic but as a principle of good governance. In addition, in the Law of the Republic of Indonesia Number 28/1999 on the Implementation of a State which Clean and Free from
Corruption, Collusion and Nepotism, referred to as general principles of public administration. However, the categories of these characteristics and principles have similarities between the moment and the others. There are various opinions about the characteristics of good governance or the word equal to the characteristics of good governance principles. Characteristics and principles of good governance each contain categories that are relevant to each other. Therefore, it is called a characteristic.

Opinions on the characteristics of good governance are as follows: First, World Bank 1995 identifies the principles of good governance including: (1) accountability; (2) participation; (3) predictability; and (4) transparency (LAN, 2003: 27). Second, UNDP 1997 identifies the principles of good governance, including: (1) participation; (2) rule of law; (3) transparency; (4) responsiveness; (5) concensus orientation; (6) equity; (7) effectiveness and efficiency; (8) accountability; and (9) strategic vision; (LAN, 2003: 27). Thirdly, UNDP 1999 identifies the characteristics of good governance, including: (1) Interaction; (2) Communication; (3) Self-Enforcing Process; (4) Dynamic; and (5) Dynamic Interdepence (LAN, 2003: 24). Fourth, UNESCAP (2009) identifies the characteristics of good governance, including: (1) participation; (2) rule of law; (3) transparency; (4) responsiveness; (5) consensus oriented; (6) equity and inclusiveness; (7) effectiveness and efficiency; (8) accountability (UNESCAP, 2009). Fifth, the Law of the Republic of Indonesia Number 28/1999 on the Implementation of the State that Clean and Free from KKN, identify general principles of state administration include: (1) legal certainty; (2) the orderly principle of state administration; (3) the principle of public interest; (4) the principle of openness; (5) the principle 
of proportionality; (6) the principle of professionalism; (7) the principle of accountability (LAN, 2003: 27).

Based on thefiveopinions, thenselected one of them to be studied. The researchers chose the UNESCAP's characteristics in 2009 that contained eight categories. The reason, the characteristics of good governance of UNESCAP's have in common with other good governance characteristics and principles; and the novelty of UNESCAP's good governance characteristics compared to other characteristics. In addition, there are limitations of researchers.

The following are the main areas of the UNESCAP's characteristics and its annotation. Good governance has 8 major characteristics. It is participatory, consensus oriented, accountable, transparent, responsive, effective and efficient, equitable and inclusive and follows the rule of law. It assures that corruption is minimized, the views of minorities are taken into account and that the voices of the most vulnerable in society are heard in decision-making. It is also responsive to the present and future needs of society (UNESCAP, 2009).

\subsubsection{Participation}

Participation by both men and women is a key cornerstone of good governance. Participation could be either direct or through legitimate intermediate institutions or representatives. It is important to point out that representative democracy does not necessarily mean that the concerns of the most vulnerable in society would be taken into consideration in decision making. Participation needs to be informed and organized. This means freedom of association and expression on the one hand and an organized civil society on the other hand.

\subsubsection{Rule of law}

Good governance requires fair legal frameworks that are enforced impartially. It also requires full protection of human rights, particularly those of minorities. Impartial enforcement of laws requires an independent judiciary and an impartial and incorruptible police force.

\subsubsection{Transparency}

Transparency means that decisions taken and their enforcement are done in a mannerthat follows rules and regulations. It also means that information is freely available and directly accessible to those who will be affected by such decisions and their enforcement. It also means that enough information is provided and that it is provided in easily understandable forms and media.

\subsubsection{Responsiveness}

Good governance requires that institutions and processes try to serve all stakeholders within a reasonable timeframe.

\subsubsection{Consensus Oritented}

There are several actors and as many view points in a given society. Good governance requires mediation of the different interests in society to reach a broad consensusin society on whatisin the best interest of the whole community and how this can be achieved. It also requires a broad and long-term perspective on what is needed for sustainable human development and how to achieve the goals of such development. This can only result from an understanding of the historical, cultural and social contexts of a given society or community.

\subsubsection{Equity and Inclusiveness}

Equity and Inclusiveness. A society's well being depends on ensuring that all its members feel that they have a stake in it and do not feel excluded from the mainstream of society. This requires all groups, but particularly the most vulnerable, have opportunities to improve or maintain their well being.

\subsubsection{Effectiveness and Eficiency}

Effectiveness and efficiency. Good governance means that processes and institutions produce results that meet 
the needs of society while making the best use of resources at their disposal. The concept of efficiency in the context of good governance also covers the sustainable use of natural resources and the protection of the environment.

\subsubsection{Accountability}

Accountability is a key requirement of good governance. Not only governmental institutions but also the private sector and civil society organizations must be accountable to the public and to their institutional stakeholders. Who is accountable to whom varies depending on whether decisions or actions taken are internal or external to an organization or institution. In general an organization or an institution is accountable to those who will be affected by its decisions or actions. Accountability cannot be enforced without transparency and the rule of law.

\subsection{Islamic Characteristics of Governance}

Scholars have generally known and understood the characteristics of the good governance. However, few of them know and understand the characteristics of Islamic governance. The characteristics of the Islamic governance and ethics sourced from the Qur'an and Hadith Prophet Muhammad (PBUH), among others: (1) Ta'awun (Participation); (2) Shari'ah (Rule of law), (3) Bayan (Transparency); (4) AtTabayun (Responsiveness); (5) Shura (Consensus orientation; (6) 'Adl (Equity \& Inclusiveness; (7) Itqan \& Tawazun (Effectiveness \& Efficiency); and (8) Mas'uliyah (Accountability).

\subsubsection{Ta'awun}

The word of "ta'awun" is equivalent to the word of "cooperation" or "participation" (Junaid, 2011: 79) which is one of the characteristics of good governance. Ta'awunismutual helpwhich is heavily commanded in the teachings of Islam.The word of "ta'awun" as stated in Surat Al-Maaidah: ... Wa ta'awanu 'alal birri wat taqwa wa la ta'awuna'alal ismi wal udwani wat taqullah, innallaha syadidul 'iqab (Al-Maa'idah, 5: 2). . Meaning, ... Help ye one another in tighteousness and piety, but help ye not one another in sin and rancor: fear Allah: for Allah is strict in punishment. The same thing, as stated in Surat AtTaubah: Wal mu'minuna wal u'minatu ba'duhum auliya'u ba'd. Ya'muruna bil ma'rufi way an hauna a'nil mungkari wa yuqimunas salata wa yu'tunaz zakata wa yuti'unallaha wa rasulah ... (At-Taubah, 9: 71). Meaning, The believers, men and women, are protectors, one of another: the enjoin what is just, and forbid what is evil ... So, ta'awun is cooperation or mutual help in doing good but not in doing evil or violation.

Hafidhuddin \& Tanjung (2003: 41) describes ta'awun (Abdullah, 2013: 59) as a work ethic of shariah management that can be seen in the form of participation, deliberation, delegation of authority, and congregation. Example: (1) Deliberation and participation. Prophet Muhammad (PBUH) is the leader who always invites the friends to participate through the deliberative approach. Companions are given the opportunity to participate in issuing fresh ideas and thoughts and responsibilities in overcoming the problems faced by Muslims at that time, among others, the idea of making khandaq (ditch) originating from a friend named Salman al-Farisi; (2) Delegation of authority. Prophet Muhammad (PBUH) does not directly hold all affairs but is delegated to the right people. Zaid bin Thabit was authorized to write revelation; and Muadz bin Jabal as zakat officers, and others; and (3) congregation. It means done together. Islam emphasizes the importance of congregation. Congregation is very necessary to be done so the job is not bored and at random. 
In practice, ta'awun can be seen as one of the characteristics of Islamic governance in public service. Ta'awun guarantees the passage of work and position to achieve organizational goals well. Ta'awun can be done in the form of deliberation, participation of material and morale. Ta'awun attitude is very big influence in bonding ukhuwah. Therefore, members of the organization must perform ta'awun in carrying out the job and position to achieve the goal better.

\subsubsection{Shari'ah}

The word of "shari'ah" is the equivalent to the word of "rule of law" which is one of the characteristics of good governance. Shariah is Islamic religious law derived from the Holy Qur'an and the sunnah (Iqbal \& Lewis, 2009). Sinn (2012: 250) states, shari'ah regulates about worship, law and mu'amalah. Mu'amalah in the social environment holds to the values of shari'ah. In other words, mu'amalah is a matter that discusses aspects of the relationship between one human and another and the existence of bonds of rights and duties. The word of "shariah" as stated in Surat Al-Maidah: ... likullin ja'alna mingkum syir'ataw wa min haja... (Al Maidah, 5: 48). Meaning, To each among you have We orescrubed a Law and an open Way. The same thing, as stated in Surat Al-Jatsiyah: Tsumma ja'alnaka 'ala syari'atim minal amri fattabi'ha ... (Al-Jatsiyah, 45: 18). Meaning, Then We put thee on the (right) Way of Religion: so follow thou that (Way).

In practice, shari'ah can be seen as one of the characteristics of Islamic governance in public service. This can be seen from the work and occupation to achieve organizational goals implemented with the basis of shari'ah values. Shari'ah in Islamic governance as an ethical value by members of the organization. Therefore, members of the organization must implement the shari'ah in carrying out the work and position to achieve the goal better.

\subsubsection{Bayan}

The word of "bayan" is equivalent to the word of "transparancy" which is one of the characteristics of good governance. Kamaruzaman \& Hashi (2011: 34) connects bayan and transparency. AlBayan is another name of the Holy Qur'an which means light for all mankind, and instruction and lessons for the righteous. The word of "bayan" as stated in Surat Ali Imran: Haza bayanul linnasi wa hudaw wa mau'izatul lil muttaqin, (Ali Imran, 3: 138). Meaning, Here is a plain statement to men, a guidance and instruction to those who fear Allah!

In practice, bayan can be seen as one of the characteristics of Islamic governance in public service. This can be seen from jobs and positions conducted according to clear guidelines to achieve organizational goals. Bayan in Islamic governance serve as an ethical value by members of the organization. Therefore, the members of the organization must implement the bayan in carrying out the work and position to achieve the goal better.

\subsubsection{At-Tabayun}

The word of "at-tabayun" is equivalent to the word of "responsiveness" which is one of the characteristics of good governance. In management shar'iah can be found at-tabayun values that must be careful, check and recheck and clarification (Hafidhuddin and Tanjung, 2003: 184). At-tabayun is checking the truth of information received to make the right decision. The word of "at-tabayun" as stated in Surat Al-Hujarat: Ya ayyuhal lazina amanu in ja'akum fasiqum bi naba'in fatabayyanu an tusibu qaumam bi jahalatin fa tushibu ala ma fa'altum nadimin (Al-Hujarat, 49: 6). Meaning, $\mathrm{O}$ ye who believe! If a wicked a person comes to you with any news, ascertain the truth, lest ye harm people unwittingly 
and afterwards become full of rentance for what ye have done.

Asbabun nuzul this verse is explained by Hafidhuddin \& Tanjung (2003: 184), that there is one who comes to the Companions who give news that a community group will not obey Prophet Muhammad (PBUH) in paying zakat. Upon hearing this, Prophet Muhammad (PBUH) then prepared troops with other companions to attack the community. However, it turns out there is another news that the news was deliberately blamed with the intention that there is a conflict among the Muslims. This person is said to be a liar and hypocrites who are fond of delivering false news.

In practice, at-tabayun can be seen as one of the characteristics of Islamic governance in public service. The organization at this time is very much receive information from various sources. Therefore, it is necessary to manage information by selecting and sorting information so that the correct information is obtained to make the right decision. At-tabayun in Islamic governance serve as an ethical value. The organization official receiving the information should verify theinformation to make the right decision. With the application of at-tabayun then the effort of governance to achieve organizational goals can be done better.

\subsubsection{Shura}

The word of "shura" is equivalent to the word of "consensus orientation" which is one of the characteristics of good governance. Shura is consultation, deliberating, taking councel (Iqbal \& Lewis, 2009). The word of "shura" as stated in Surat Asyura: ... wa amruhum syura bainahum ... (Asyura, 42: 38). Meaning, who (conduct) their affairs by mutual consultation. The same thing, as stated in Surat Ali Imran: ... wa syawirhum fil amri fa iza azamta fatawakkal allallah, innallaha yuhibbul mutawakilin (Ali
Imran, 3: 159). Meaning, ... and consult them in affairs (of moment). Then, when thou has taken a decision, put thy trust in Allah. For Allah loves those who put their trust (in Him).

Hafidhuddin \& Tanjung (2003: 123) states, Islam recommends to cultivate shura among fellow believers. Whatever is done, should be through shura should not be their own way. Thus, shura is one of many values taught in Islam that must be implemented. In other words, shura is a good job because it gives happiness to the life of the world and the hereafter. In practice, shura can be seen as one of the characteristics of Islamic governance in public service. This can be seen from the decision making in the organization done in shura. With shura, efforts to achieve goals can be achieved better. Therefore, shura is one of the ethical values that must be applied in Islamic governance.

\subsection{6. 'Adl}

The word "'adl" is equivalent to the word "justice" (Iqbal \&Lewis (2009) and "fairness" (Junaid, 2011: 84). This word is used to compare the managerial ethics between management theories and Islam. Meanwhile, the word "fairness" (Kamaruzaman \& Hazhi, 2011: 32) and the word "justice" are equivalent to "equity" (Loqman \& Bulbul, 2011: 9; Mohiuddin, 29). Thus, the word of "'adl" is equivalent to the word of "equity" and "inclusiveness", which is one of the characteristics of good governance.

The word of "'adl" as stated in Surat An-Nisa': ... Wa idza hakamtum bainan nasi antahkum bil 'adl ... (An-Nisa', 4: 58). Meaning, $\ldots$ and when ye judge between man and man, that ye judge with justice. The same thing, is stated in Surat An-Nahl: Innallaha ya'muru bil'adli wal ihsanbi wa ita'izil qurba wa yanha anil fahsya'I wal munkari wal bagyi ya'izukum la'allakum tazakkarun (An-Nahl, 16: 90). Meaning, Allah commands justice, the doing of good and 
liberality to kith and kin, and He forbids all shamefull deeds, and injustice and rebellion: He instruct you, that ye may receive admonition. Furthermore, is stated in Surat Al-Maidah: ... i'dilu, huwa aqrabu lit taqwa wat taqullah .... (AlMaidah, 5: 8). Meaning, ... Be just: that is next to piety: and fear Allah.

Thus, 'adl is one of the many values taught in Islam that must be exercised. In other words, 'adl is a good job because it gives happiness to the life of the world and the hereafter. That is why justice becomes an important thing to implement. For example, in a country, justice serves as a principle for its citizens. This can be seen from the $5^{\text {th }}$ principle of Pancasila "Social Justice for All Indonesian People”.

In practice, 'adl can be seen as one of the characteristics of Islamic governance in public service. Organizations that apply the principles of 'adl reflect the organization led by the cautious (Hafidhuddin \& Tanjung, 2008: 29). Members of the organization must do 'adl in carrying out their duties and responsibilities. This can be seen from the implementation of duties and responsibilities in the organization fairly. By doing 'adl' the governance of members of the organization to achieve its goals can be done better.

Furthermore, as already mentioned, that "adl" is equivalent to the word of "justice" or "inclusiveness", which is one of the characteristics of good governance. Decision of Fatwa of Indonesian Ulema Council Number: 7/Munas VII/MUI/11/2005 About Pluralism, Liberalism, and Religious Secularism. The contents of this Decision, among others, in social issues that are not related to aqidah and worship, Muslims are inclusive (MUI, 2007), in the sense of staying social with other religions as long as it is not mutually harmful.

The basis of the decision comes from the Qur'an and the Sunnah of the Prophet, as follows: (1) Surat Al-Mumtahanah explained: La yanhakumullahu 'anil lazina lam yuqatilukum fiddini wa lam yukhrijukum min diyarikum an tabarruhum wa tuqsitu ilaihim, innallaha yuhibbul muqsitin. (Al-Mumtahanah, 6o: 8). Meaning, Allah forbids you not, for those of you who fight you not for (your) Faith nor drive you out of your homes, from dealing kindly and justly with them: for Allah loveth those who are just. (2) Prophet Muhammad (PBUH) socialize well with non-Muslim communities such as Jewish communities living in Khaibar and Nazarene who live Najran, even one of the Prophet's in-laws Huyay bin Ahthab is a Jewish figure from Bani Quraizhah (Sayyid Quraizhah). (The history of al-Bukhari and Muslim).

Ya'qub (2001: 111) states, in cooperation with people who are nonMuslims in the field of business world, business, industry and others that concern economic interests is basically not forbidden. In other words, may cooperate with them, as long as they do not show hostility towards the ummah of Islam and the fields that are tilled do not destroy belief, shari'ah and morality Islami.

\subsection{7. 'Itqan and Tawazun}

The words of "itqan" and "tawazun" are equivalent to the words of "effectiveness" and "efficiency" which are characteristic of good governance. Let us discuss it one by one. In this case. will be discussed about itqan then tawazun. Itqan is the sincerity and stability in carrying out a task, so that it is done maximally, not carelessly, until the work is complete and finished well (Hafidhuddin \& Tanjung, 2003: 40). Prophet Muhammad (PBUH) said, "Indeed Allah loves a man who when doing a job, then the work is done with itqan." (HR Thabrani). The word of "itqan" as stated in Surat An-Naml: ... shun'allahil ladzi atqana kulli syai' 
(An-Naml, 27: 88) ... Meaning, ... Who disposes of all things in perfect order.

Furthermore, tawazun is a balance. Tawazun means living balance, acting and acting in harmony, natural, not wasteful, but not miserly or stingy, Islam governs human beings in order to live in harmony, and balanced and fair (Effendy, 2009: 154). The word of "tawazun" as stated in Surat ar-Rahman: Was sama'a rafa'aha wa wada al mizan (Ar-Rahman, 55: 7). Meaning, And the Firmament has He raised high, and He has set up the Balance (of Justice).

According to Hafidhuddin \& Tanjung (2003: 37) "tawazun" is the opposite of "israf" and "mubazir". Tawazun is something that is recommended while israf and mubazir is something that is forbidden and not loved by Allah SWT. In an organization must also tawazun, should not be "israf" and "mubazir". What is an israf and mubazir? Israf is extravagance and a such condomned in Islam (Iqbal \& Lewis, 2009) The word of "israf" as stated in Surat Al-A'raaf: ... wa kulu wasyrabu wala tusrifu innahu la yuhibbul musrifin (Al-A'raaf, 7:31). Meaning ... Eat and drink: but waste not by excess, for Allah loveth not wasters. This verse teaches tawazun and forbids israf. While, the word of "mubazir" as stated in Surat Al-Isra: Innal mubazzirina kanu ikhwanasy syayatin. Wa, kanasy syaitanu li rabbihi kafura (Al-Isra, 17: 26). Meaning, Verily spendthrisfts are brothers of the Evil Ones, and the Evil One is to his Lord (Himself) ungrateful.

In practice, itqan and tawazun can be seen as one of the characteristics of Islamic governance in public service. Based on the above description, both itqan and tawazun in Islamic governance serve as an ethical value by members of the organization. This can be seen from occupations and positions conducted in itqan and tawazun to achieve organizational goals. By applying the principles of itqan and tawazun, then efforts to achieve goals can be done better. Therefore, members of the organization must carry out their work and positions in an itqan and tawazun.

\subsubsection{Mas'uliyah}

The word of "mas'uliyah" is equivalent totheword of "accountability" whichisone of the characteristics of good governance. The concept of accountability which is the hallmark of Islam (Mahmood, 2001: 14). Kamaruzaman \& Hazhi (2011: 32) membandingkan managerial ethics between management theories and Islam, dengan cara membandingkan antara accountability dan mas'uliyah.

The word of "mas'uliyah" as stated in Surat Al-Isra: Wa la taqfu ma laisa laka bihi 'ilm, innas sam'a wal basara wal fu'ada kullu ula'ika kana 'anhu mas'ula (Al-Isra, 17: 36). Meaning, And pursue not that of which thou hast no knowledge; for every act of hearing, or of seeing, or of (feeling in) the heart wil be enquired into (on the Day of Reckoning). The same thing, as stated in Surat AzZalzalah: Famay ya'ma; mitsqala zarratin kahiray yarah.Wamay ya'mal mitsqala zarrtatin syarray yarah (Az-Zalzalah, 99: 6-7). Meaning, Then shall anyone who has done an antom's weight of good, see it.And anyone who has done an atom's weight of evil, shall see it.

Thus, Mas'uliyah is accountable for the work done. Whether or not a person's actions will be held accountable not only in the world, but in fact there is accountability in the next (hereafter) called reckoning. In practice, mas'uliyah can be seen as one of the characteristics of Islamic governance in public service. This can be seen in the organization, every person in carrying out his job and his position is demanded responsibility. Furthermore, positions held by man is a mandate from God that will be accounted before him someday (Hafidhuddin \& Tanjung, 2003: 35). This can be seen 
from the passage of jobs and positions in organizations mas'uliyah. By applying mas'uliyah then the effort of governance to achieve organizational goals can be done well. Therefore, members of the organization must carry out the job and position in mas'uliyah.

\subsection{Related Studies on Islamic Governance}

This study was conducted through a review of the literature of research results relevant to the Public Administration an Islamic Perspective. This research is conducted to find out what needs to be done in the framework of development of public administration. From the results of literature review that has been done, can be collected 37 (thirdty sevent) articles the International Discourse of Islamic Governance and Ethics 2012-2018. The titles of these articles are in table 1.

The results of international discourses on Islamic governance 2010-2017 as many as 37 articles on Islamic governance, based on data collection using the website. The average article on Islamic governace annually generated between 4 and 5 articles. This means that the resulting article is very small. The causes include international conference on Islamic governance rarely done every year; and the writing of articles on Islamic governance is not productive because the author of good governance in the perspective of Islam their number of few; whereas the authors of good governance in Western perspective or conventional number of them a lot.

Title groups and study types by titles of articles on Islamic governance. First, the group according to the title of the article, include: (1) Islamic governance (13 articles); (2) Sharia governance (11 articles); (3) Governance in Islam (6 articles); (4) Governance Islamic (2 articles); (5) Governance of Islam in Qur'an; (6) Islam for governance; (7) Islam and Governance; and (8) Qur'anic
Governance, each 1 article. Second, the group by type of study, including: (1) Deskriptive qualitative (20 articles); (2) applied study (7 articles); (3) comparative study (5 articles); (4) survey (3 articles); (5) correlation study; (6) Islamic though; and (7) evaluation study, each 1 article.

\begin{tabular}{|c|c|c|}
\hline Year & Authors & $\begin{array}{c}\text { Titles of Articles on Islamic } \\
\text { Governance }\end{array}$ \\
\hline \multirow[t]{2}{*}{2010} & $\begin{array}{l}\text { Kamaruddin, } \\
\text { Zaleha }\end{array}$ & $\begin{array}{l}\text { 1. A Malaysian Perspective } \\
\text { on Qur'anic Governance }\end{array}$ \\
\hline & Khan, Muqtedar & $\begin{array}{l}\text { 2. Democracy is } \\
\text { Indispensable: A Political } \\
\text { Philosophy of Islamic } \\
\text { Governance }\end{array}$ \\
\hline \multirow[t]{8}{*}{2011} & Hamid et al. & $\begin{array}{l}\text { 3. The Comparison of the } \\
\text { Characteristics of The } \\
\text { Anglosaxon Governance } \\
\text { Model and The Islamic } \\
\text { Governance of IFIS }\end{array}$ \\
\hline & Hasan, Zulkifli & $\begin{array}{l}\text { 4. A survey on Shari'ah } \\
\text { governance practices in } \\
\text { Malaysia, Gulf Cooperation } \\
\text { Countries and the United } \\
\text { Kingdom: Critical appraisal }\end{array}$ \\
\hline & Malik Maszlee & $\begin{array}{l}\text { 5. Constructing the } \\
\text { Architectonics \& the } \\
\text { Articulation of Islamic } \\
\text { Governance }\end{array}$ \\
\hline & Malkawi \& Sonn & $\begin{array}{l}\text { 6. Ibn Taymiyya on Islamic } \\
\text { Governance }\end{array}$ \\
\hline & Naqvi et al. & $\begin{array}{l}\text { 7. The model of Good } \\
\text { Governance in Islam }\end{array}$ \\
\hline & Ozkan, Necmetin & $\begin{array}{l}\text { 8. Principles of Islam for } \\
\text { information technology } \\
\text { governance }\end{array}$ \\
\hline & Shaharuddin, A & $\begin{array}{l}\text { 9. Shariah Governance of } \\
\text { Malaysian Islamic Banking }\end{array}$ \\
\hline & Welsh, Bridget & $\begin{array}{l}\text { 10. New Islamic Governance: } \\
\text { The Parti Islam Se- } \\
\text { Malaysia \& Parti Keadilan } \\
\text { Sejahtera Evolution }\end{array}$ \\
\hline \multirow[t]{4}{*}{2012} & $\begin{array}{l}\text { Azram, } \\
\text { Mohammad }\end{array}$ & $\begin{array}{l}\text { 11. Principles of Good } \\
\text { Governance in Islam }\end{array}$ \\
\hline & $\begin{array}{l}\text { Bouzenita, Anke } \\
\text { Iman }\end{array}$ & $\begin{array}{l}\text { 12. Early Contributions } \\
\text { to the Theory of Islamic } \\
\text { Governance }\end{array}$ \\
\hline & Islam, MN & $\begin{array}{l}\text { 13. Understanding Good } \\
\text { Governance in Islam: A } \\
\text { conceptual analysis }\end{array}$ \\
\hline & Minhas, Imran & $\begin{array}{l}\text { 14. Shari'ah Governance } \\
\text { Model and Its Four Basic } \\
\text { Pillars }\end{array}$ \\
\hline
\end{tabular}


Hasanuddin Economics and Business Review

Vol. 2 No. 2 (123-141)

\begin{tabular}{|c|c|c|}
\hline \multirow[t]{3}{*}{2013} & $\begin{array}{l}\text { Alireza \& } \\
\text { Ebrahemi }\end{array}$ & $\begin{array}{l}\text { 15. The Global Governance } \\
\text { of Islam in Quran }\end{array}$ \\
\hline & $\begin{array}{l}\text { Drechsler, } \\
\text { Wolfgang }\end{array}$ & $\begin{array}{l}\text { 16. Three paradigms of } \\
\text { Governance: Chinese, } \\
\text { Western and Islamic }\end{array}$ \\
\hline & Salim et al. & $\begin{array}{l}\text { 17. Shariah Governance and } \\
\text { Corporate Governance }\end{array}$ \\
\hline \multirow[t]{3}{*}{2014} & Ismail \& Razak & $\begin{array}{l}\text { 18. Shariah Governance } \\
\text { Framework Gaps and Issues }\end{array}$ \\
\hline & $\begin{array}{l}\text { Muneeza, } \\
\text { Aishath }\end{array}$ & $\begin{array}{l}\text { 19. Shari'ah Governance } \\
\text { Applicable to Islamic Banks } \\
\text { in Malaysia }\end{array}$ \\
\hline & Obid \& Naysar & $\begin{array}{l}\text { 20. Toward a comprehensive } \\
\text { theoretical framework for } \\
\text { Shariah Governance in } \\
\text { Islamic financial institutions }\end{array}$ \\
\hline \multirow[t]{6}{*}{2015} & $\begin{array}{l}\text { Azis, Amin } \\
\text { Abdul }\end{array}$ & $\begin{array}{l}\text { 21. Governance in a } \\
\text { Contemporary Islamic } \\
\text { Negara }\end{array}$ \\
\hline & Chee, Yung Mei & $\begin{array}{l}\text { 22. Islamic Governance: } \\
\text { Strategies for Relevance }\end{array}$ \\
\hline & Ihsan \& Ayedh & $\begin{array}{l}\text { 23. A Proposed Framework } \\
\text { of Islamic Governance for } \\
\text { Awqaf }\end{array}$ \\
\hline & $\begin{array}{l}\text { Rauf, Imam } \\
\text { Feisal Abdul }\end{array}$ & $\begin{array}{l}\text { 24. Characteristics of Islamic } \\
\text { Governance:The Scholar } \\
\text { Consensus }\end{array}$ \\
\hline & & $\begin{array}{l}\text { 25. Human Rights and } \\
\text { Islamic Governance }\end{array}$ \\
\hline & & $\begin{array}{l}\text { 26. Governance from Islamic } \\
\text { economic perspective: A } \\
\text { Shari'ah Governance }\end{array}$ \\
\hline \multirow[t]{2}{*}{2016} & Alaydan, S. & $\begin{array}{l}\text { 27. Islamic finance, and the } \\
\text { standardisation of Sharia } \\
\text { Governance }\end{array}$ \\
\hline & Ismail et al. & $\begin{array}{l}\text { 28. Shariah Governance } \\
\text { Framework for Islamic Co- } \\
\text { Operatives as an Integral } \\
\text { Social Insitution in Malaysia }\end{array}$ \\
\hline \multirow[t]{5}{*}{2017} & Azmi, Mohamad & $\begin{array}{l}\text { 29. The Theological Faces of } \\
\text { Islamic Governance }\end{array}$ \\
\hline & Elghuwel et al. & $\begin{array}{l}\text { 30. Corporate governance, } \\
\text { Islamic governance \& } \\
\text { earnings manag.in Oman }\end{array}$ \\
\hline & Gigado \& Yushau & $\begin{array}{l}\text { 31. Influence of } \\
\text { accountability \& } \\
\text { transparency on Governance } \\
\text { in Islam }\end{array}$ \\
\hline & $\begin{array}{l}\text { Iqbal \& } \\
\text { Mahmood }\end{array}$ & $\begin{array}{l}\text { 32. Objectives of } \\
\text { Governance: A Comparison } \\
\text { of Islamic \& Western } \\
\text { Tradition in the Context of } \\
\text { Pakistan }\end{array}$ \\
\hline & Malik, Maszlee & $\begin{array}{l}\text { 33. Foundations of Islamic } \\
\text { Governance: A Southeast } \\
\text { Asian Perspective }\end{array}$ \\
\hline
\end{tabular}

\begin{tabular}{ll}
\hline $\begin{array}{l}\text { Moten, Abdul } \\
\text { Rashid }\end{array}$ & $\begin{array}{l}\text { 34. Al-Siyasah al- } \\
\text { Shar'iyah:Good Governance } \\
\text { in Islam }\end{array}$ \\
\cline { 2 - 2 } Naser, Abdul & $\begin{array}{l}\text { 35. Islam, People and } \\
\text { Governance }\end{array}$ \\
\hline Ronem & $\begin{array}{l}36 . \quad \text { The Evaluation of } \\
\text { Islamic Governance }\end{array}$ \\
\hline Setyowati et al. & $\begin{array}{l}\text { 37. Sharia Governance on } \\
\text { Islamic Banking: Spiritual } \\
\text { Rights Perspective on } \\
\text { Consumer Protection in } \\
\text { Indonesia }\end{array}$ \\
\hline
\end{tabular}

Based on the international discourses on Islamic governance 2010-2017, it is known that the research entitled the comparison of UNESCAP's Characteristics of Good Governance and Islamic Characteritic of Governance for public services reform in Indonesia, not yet done by other researchers. This study may be included in a group of articles under the title Islamic governance; and the comparative study type group, this study is expected to increase the number of research on Islamic governance that the number is small.

\section{METHODOLOGY}

The study used library research method, based on Holy Qur'an and Hadith Nabawi, relevant textbooks and websites, with direct observation in the field. Collecting and analyzing data based on descriptive qualitative method.

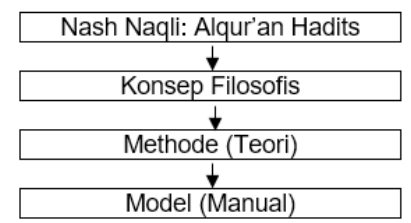

Figure 1: Logical Framework Islamic Characteristics of Governance

Data collection in the study of Islamic governance, carried out by borrowing logical framework developed by Ahmad Tafsir (2012). Ahmad Tafsir (2012: 312) states in developing Islamic science education theory, we must start from verses of al-Qur'an or hadith, then philosophical theory accordingly, after that scientific theory. The step is taken 
to ensure the integration of knowledge qur'aniyah and knowledge kauniyah. This is the grand theory to produce a theory of knowledge that is not secular. According to him, at least developing the theory is done by way of consultation on revelation. Consultation on revelation is necessary so that the theories are not contrary to revelation. (Tafsir, 1995: 4). Therefore, a Logical Framework Islamic Characteristics of Governance (see figure 1) can be drawn up. The results of the logical framerork process of Islamic characteristics of governance are presented in point 2.2.

Furthermore, an analysis of Islamic characteristic of governance is produced. The analysis of this research using comparative study method. To compare can be defined broadly as' to estimate the similarity or difference between things. Comparative analysis was conducted to answer the research question, what is differences and similarities between UNESCAP's Characteristics of Good Governance and Islamic Characteristics of Governance? This study was conducted in Indonesia, in the first half of 2018.

\section{FINDINGS/DISCUSSION}

Comparison of Islamic Governance Characteristics with UNESCAP's Characteristics is useful for use in the context of good bureaucracy and public services. The results of the literature research indicate that Islamic Governance Characteristics offers principles and ethics for bureaucracy and good public service in Indonesia. Based on UNESCAP's Characteristics of Good Governance and Governance Characteristics from Islamic Perspectives that have been described in point 2.1. and 2.2, there can be compiled a table on Comparison between UNESCAP's Characteristics of Good Governance and Islamic Characteristics of Governance, as can be seen in table 2 .
Tabel 2: Comparison between UNESCAP's Characteristics of Good Governance and Islamic Characteristics of Governance

\begin{tabular}{|c|c|c|}
\hline No. & $\begin{array}{l}\text { UNESCAP's Characteris- } \\
\text { tics of Good Governance }\end{array}$ & $\begin{array}{c}\text { Islamic Characteristics } \\
\text { of Governance }\end{array}$ \\
\hline 1 & $\begin{array}{l}\text { Participation } \\
\text { - Participation by both } \\
\text { men and women is } \\
\text { a key cornerstone of } \\
\text { good governance; } \\
\text { - Participation needs } \\
\text { to be informed and } \\
\text { organized; } \\
\text { - Example could be ei- } \\
\text { ther direct or through } \\
\text { legitimate intermediate } \\
\text { institutions or repre- } \\
\text { sentatives. }\end{array}$ & $\begin{array}{l}\text { Ta'awun. } \\
\text { - The believers, men } \\
\text { and women, are } \\
\text { protectors, one of the } \\
\text { other: the enjoin what } \\
\text { is just, and forbid } \\
\text { what is evil; } \\
\text { - Cooperation or mutual } \\
\text { help is done for good } \\
\text { but not to commit any } \\
\text { offense or sin; } \\
\text { - Example of deliber- } \\
\text { ation, delegation of } \\
\text { authority, and congre- } \\
\text { gation. }\end{array}$ \\
\hline 2 & $\begin{array}{l}\text { Rule of Law } \\
\text { - fair legal frameworks } \\
\text { that are enforced } \\
\text { impartially; } \\
\text { - enforcement of laws } \\
\text { requires an indepen- } \\
\text { dent judiciary and an } \\
\text { impartial and incor- } \\
\text { ruptible police force; } \\
\text { - protection of human } \\
\text { rights, particularly } \\
\text { those of minorities. }\end{array}$ & $\begin{array}{l}\text { Shari'ah } \\
\text { - Islamic religious law } \\
\text { derived from the } \\
\text { Holy Qur'an and the } \\
\text { sunnah; } \\
\text { - the law must be en- } \\
\text { forced fairly; } \\
\text { - muamalah regulate } \\
\text { relationships between } \\
\text { people and bonds of } \\
\text { rights and obligations. }\end{array}$ \\
\hline 3 & $\begin{array}{l}\text { Transparency } \\
\text { - decisions taken and } \\
\text { their enforcement in } \\
\text { a manner that follows } \\
\text { rules and regulations; } \\
\text { - information is freely } \\
\text { available and directly } \\
\text { accessible to those who } \\
\text { will be affected by such } \\
\text { decisions enforcement. }\end{array}$ & $\begin{array}{l}\text { Bayan } \\
\text { There is a clear explana- } \\
\text { tion for all men, a guid- } \\
\text { ance and instruction to } \\
\text { those who fear Allah. }\end{array}$ \\
\hline 4 & $\begin{array}{l}\text { Responsiveness } \\
\text { Good governance } \\
\text { requires that institutions } \\
\text { and processes try to } \\
\text { serve all stakeholders } \\
\text { within a reasonable } \\
\text { timeframe. }\end{array}$ & $\begin{array}{l}\text { At-Tabayun } \\
\text { Receiving information } \\
\text { should be checked care- } \\
\text { fully, check and recheck } \\
\text { and clarify the real } \\
\text { situation in order not to } \\
\text { take the wrong decision } \\
\text { and cause regret. }\end{array}$ \\
\hline
\end{tabular}




\begin{tabular}{|c|c|c|}
\hline 5 & $\begin{array}{l}\text { Consensus Orientation } \\
\text { - There are several } \\
\text { actors and as many } \\
\text { view points in a given } \\
\text { society; } \\
\text { - requires mediation of } \\
\text { the different interests } \\
\text { in society to reach a } \\
\text { broad consensus in } \\
\text { society; } \\
\text { - requires a broad and } \\
\text { long-term perspective } \\
\text { for human devel- } \\
\text { opment and how to } \\
\text { achieve the goals of } \\
\text { such development. }\end{array}$ & $\begin{array}{l}\text { Shura } \\
\text { - The work affairs con- } \\
\text { cerning the common } \\
\text { good may not be } \\
\text { solved alone; } \\
\text { - The settlement of } \\
\text { work affairs is done } \\
\text { through deliberations } \\
\text { between stakeholders } \\
\text { to take decisions; } \\
\text { - Making decisions is } \\
\text { committed with full } \\
\text { of determination and } \\
\text { trust in God. }\end{array}$ \\
\hline 6 & $\begin{array}{l}\text { Equity \& Inclusiveness } \\
\text { - A society's well being } \\
\text { depends on ensuring } \\
\text { that all its members } \\
\text { feel that they have a } \\
\text { stake in it and do not } \\
\text { feel excluded from the } \\
\text { mainstream of society; } \\
\text { - This requires all } \\
\text { groups, but particular- } \\
\text { ly the most vulnerable, } \\
\text { have opportunities to } \\
\text { improve or maintain } \\
\text { their well being. }\end{array}$ & $\begin{array}{l}\text { 'Adl } \\
\text { - Allah commands men } \\
\text { to do justice, do good, } \\
\text { and forbid the abom- } \\
\text { inations, munkar and } \\
\text { hostility; } \\
\text { - Inclusiveness, in the } \\
\text { sense of keeping social } \\
\text { intercourse with other } \\
\text { religions as long as } \\
\text { it is not mutually } \\
\text { harmful, not related to } \\
\text { aqidah and worship. }\end{array}$ \\
\hline 7 & $\begin{array}{l}\text { Effectiveness \& Effi- } \\
\text { ciency } \\
\text { - processes and institu- } \\
\text { tions produce results } \\
\text { that meet the needs of } \\
\text { society while making } \\
\text { the best use of resourc- } \\
\text { es at their disposal; } \\
\text { - the concept of efficien- } \\
\text { cy in the context of } \\
\text { good governance also } \\
\text { covers the sustainable } \\
\text { use of natural resourc- } \\
\text { es and the protection } \\
\text { of the environment. } \\
\end{array}$ & $\begin{array}{l}\text { Itqan \& Tawazun } \\
\text { - sincerity and stability } \\
\text { in carrying out the } \\
\text { task, not careless, so } \\
\text { that the work complet- } \\
\text { ed and finished well; } \\
\text { - the existence of bal- } \\
\text { ance, act and act har- } \\
\text { monious, reasonable, } \\
\text { not wasteful, but not } \\
\text { miserly or stingy. }\end{array}$ \\
\hline 8 & $\begin{array}{l}\text { Accountability } \\
\text { - governmental insti- } \\
\text { tutions, the private } \\
\text { sector and civil society } \\
\text { organizations must } \\
\text { be accountable to the } \\
\text { public and to stake- } \\
\text { holders; } \\
\text { - Who is accountable to } \\
\text { whom varies depend- } \\
\text { ing on whether deci- } \\
\text { sions or actions taken } \\
\text { are internal or external } \\
\text { to an organization. }\end{array}$ & $\begin{array}{l}\text { Mas'uliyah } \\
\text { - for every act of hear- } \\
\text { ing, or of seeing, or of } \\
\text { feeling in the heart wil } \\
\text { be inquired into the } \\
\text { Day of Reckoning; } \\
\text { - Good or bad one's } \\
\text { actions will be held } \\
\text { accountable not only } \\
\text { in the world, but in } \\
\text { tomorrow (akhirat) } \\
\text { which is called by } \\
\text { hisab. }\end{array}$ \\
\hline
\end{tabular}

The comparison between UNESCAP's Characteristics of Good Governance and Islamic Characteristics of
Governance mentioned above (Table 2), presents 8 characteristics of good governance, from the UNESCAP and Islamic perspective versions that have been collected, as presented in Table 2 above. Furthermore, comparative analysis is done to find the similarities and differences between UNESCAP's Characteristics of Good Governance and Islamic Characteristics of Governance, by reviewing the annotations presented in the table. Results of analysis similarities and differences between UNESCAP's Characteristics of Good Governance and Islamic Characteristics of Governance, can be followed in the description below.

First, participation and Ta'awun: Similarities, performed by men and women, for example in deliberations and representation. Differences, ta'awun is confirmed to do good and just good and forbid bad deeds and sins. While participation does not confirm the prohibition do evil and sin. Second, Rules of Law and Sharia: Similarities, the law should be enforced fairly to protect human rights. Differences, shari'a is a command and the rule is derived from the Holy Qur'an and the sunnah. While the rule of law is a rule made by humans.

Third, Transparency and Bayan: Similarities, decisions are made under clear rules. Differences, bayan are performed to follow clear rules/directions from God. While, transparency is implemented to follow regulations made by humans. Fourth, Responsiveness and At-Tabayun: Similarities, done in providing services and making decisions. Differences, at-tabayun affirm the need for clarification of information and the actual situation so as not to take the wrong decision that causes regret. While the responsiveness confirms the information service is done within a reasonable time.

Fifth, Orientation of consensus and Shura: Similarities, done by some actors in society to achieve goals. Differences, 
shura concerning the common good and done with full determination and trust in god for the purpose of prosperity in the world and the hereafter; while the orientation of consensus is done for the purpose of being limited to the welfare of the material world. Sixth, Equity \& Inclusiveness and 'Adl: Similarities, the interests of community members are appreciated. Differences, 'adl is a rule and command from God to man to do good, forbid abominations, evil and enmity; as well as maintaining social relations with other religions as long as they are not mutually harmful, and not related to aqidah and worship. While equity \& inclusivity is done to follow the rules made by humans in social relationships.

Seventh, Effectiveness \& Efficiency with Itqan \& Tawazun: Similarities, done in tasks and jobs by utilizing resources to obtain good results. Differences, Itqan \& Tawazun, prioritize balance and harmonization but not miserly and stingy. Meanwhile, effective and efficient, prioritizing effectiveness and efficiency but no miserly and stingy measurement. Eighth, Accountability and Mas'uliyah: Similarities, government agencies, the private sector and accountability are accountable to stakeholders. Differences, Mas'uliyah asserted that every human action will be asked not only responsibility in the world but in tomorrow (hereafter) called hisab; while accountability is the only responsibility for the achievement of goals in the world.

Furthermore, based on the description above, it can be described figure 2: Islamic characteriss of governance. Islamic governance has 8 major characteristics, that gives happiness to the life of the world and the hereafter. It is shariah, 'adl, ta'awun, bayan, itqan and tawazun, shura, at-tabayun and mas'uliyah.

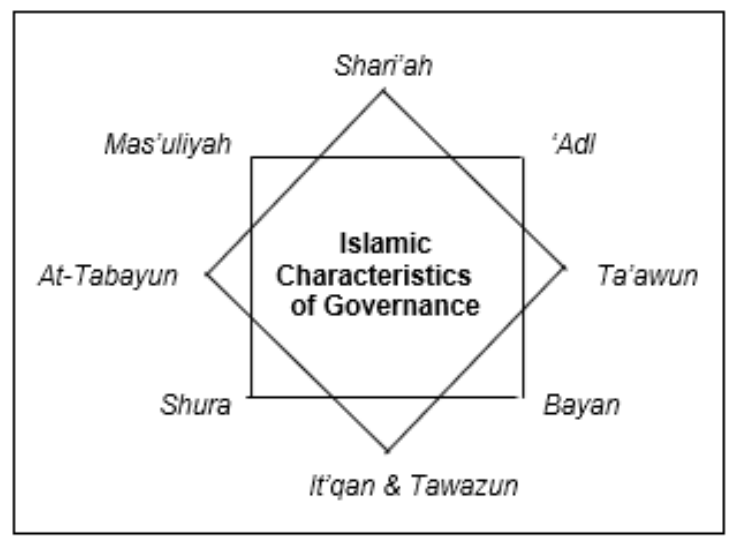

Figure 2: Islamic characteristics of governance

Between UNESCAP's Characteristics of Good Governance and Islamic Characteristics of Governance found the similarity of categories used among UNESCAP's Characteristics of Good Governance and Islamic Characteristics of Governance. For example, the rule of law is the same as shariah; and equal accountability with mas'uliyah, and others.

In addition, there are differences between UNESCAP's Characteristics of Good Governance and Islamic Characteristics of Governance. The differencesareinthecontentorannotation of categories used in both the UNESCAP's Characteristics of Good Governance and the Islamic Characteristics of Governance. The difference is caused by the use of different sources. UNESCAP's Characteristics of Good Governance is structured using sources of human reason; and a secular understanding separating reason and revelation; and an understanding of materialism that only believes in tangible objects; and do not believe in a supernatural being; as well as the understanding of liberalism that upholds freedom in doing an act. The deed done only to satisfy the material satisfaction and it only recognizes the responsibility in the world. So no wonder if no content or annotation of categories derived from religion.

In contrast, the Islamic Characteristics 
of Good Governance is compiled using the source is derived from the Holy Qur'an and the Sunnah. Annotations of categories used do not separate human reason and revelation; and is not limited to the understanding of materialism but rather acknowledges material and spiritual existence, physics/metaphysics and the unseen world as well as spiritually. Therefore, the annotations of derived categories are sourced from religion so that it does not only reach the short life and time in the world; but also to reach life and time infinite by the human mind because of life in the world and the afterlife that must be accountable to God.

The implications of Islamic characteristic of governance, then government officials must know, understand and internalize as an ethic for public service reform in Indonesia. So that public services can be well organized for the welfare of the community. The reasons, that the majority of Indonesia's population adheres to Islam as great potential toward Islamic governance and ethics for Public Services Reform in Indonesia.

\section{CONCLUSION/IMPLICATIONS}

First, between UNESCAP's Characteristics of Good Governance and Islamic Characteristics of Governance found the similarity of categories used among UNESCAP's Characteristics of Good Governance and Islamic Characteristics of Governance.

Second, in addition, there are differences between UNESCAP's Characteristics of Good Governance and Islamic Characteristics of Governance. The differences are in the content or annotation of categories used in both the UNESCAP's Characteristics of Good Governance and the Islamic Characteristics of Governance.

Third, Islamic characteristics of governance, has 8 major characteristics, consist of: shariah, 'adl, ta'awun, bayan, itqan \& tawazun, shura, at-tabayun and mas'uliyah.

Fourth, the implications of Islamic characteristic of fovernance, then government officials must know, understand and internalize as an ethic for public service reform in Indonesia.

\section{REFERENCES}

Abdullah, M. Ma'ruf (2013), Manajemen Berbasis Syariah, Yogyakarta: Aswaja Pressindo.

Arif, Rifwan Editor (2012), Al-Qur'an Tiga Bahasa, Depok: Al-Huda.

Effendy, Mochtar (2009), Manajemen suatu Pendekatan berdasarkan ajaran Islam, Palembang: Penerbit Unsri.

Hasibuan, Sayuti (2001), Manajemen Sumber Daya Manusia, Surakarta: Muhammadiyah University Press.

Iqbal, Zafar \& Lewis, Mervyn K. (2009) An Islamic Perspective on Governance, Massacusetts: Edward Elgar Publishing, Inc.

Junaid, Mohammad Rizwan (2011) "Managerial Ethics in Islamic Framework", in Ahmad, Khalik et.al (ed.), Issues in Islamic Management, Selangor: International Islamic University Malaysia Press.

Kamaruzaman, Kamar Oniah \& Hashi, Abdul Razak Abdullah (2011), "Managerial Ethics of Public Administrators from the Qur'anic Perspective", in Ahmad, Khalik et.al (ed.), Issues in Islamic Management, Selangor: International Islamic University Malaysia Press.

LAN (2003) Penyusunan Pedoman Aplikasi Prinsip-prinsip Kepemerintahan yang baik dalam Manajemen Pemerintahan, Jakarta: Lembaga Administrasi 
Negara.

Loqman, Muhammad \& Bulbul, Afroza (2011), "Convergence and Divergence between Conventional Approach and Islamic Approach to Management",in Ahmad, Khalik et.al editor, Issues in Islamic Management, Selangor: International Islamic University Malaysia Press.

Mahmood, Riaz (2001), The Concept of Administrative Accountability in Islam, Lahore: Kurshid Maqbool Press.

Naim, Akhsana \& Saputra, Hendri (2011), Kewarganegaraan Suku Bangsa, Agama dan Bahasa Seharihari Penduduk Indonesia: Hasil Sensus Penduduk 2010, Jakarta: Badan Pusat Statistik.

Sinn, Ahmad Ibrahim Abu (2012) Manajemen Syariah: Sebuah Kajian Historis dan Kontemporer, Jakarta: Rajawali Pers.

Tafsir, Ahmad (2012) Ilmu Pendidikan Islami, Bandung, PT Remaja Rosdakarya.

(1995) Epistemologi untuk Ilmu Pendidikan Islam, Bandung: Fakultas Tarbiyah IAIN Sunang Gunung Jati.

Tanjung, Hendri (2014), Manajemen Syariah dalam Praktik 9 Nabi dan Rasul, Jakarta: Penerbit PT Elex Media Komputindo.

Wiryanto, Wisber (2016) Islamisasi Buku Ajar Materi Sumber Daya Manusia dalam Perspektif Ismail Raji Al-Faruqi, Sinopsis Disertasi, Universitas Ibn Khaldun Bogor.

Ya'qub, Hamzah (2001) Etos Kerja Islami: Petunjuk Pekerjaan yang Halal dan Haram dalam Syariat Islam. Jakarta: Pedoman Ilmu Jaya.

Website:

Alaydan, S. (2016) Islamic finance,
Sharia non-compliance and the standardisation of Sharia Governance. Doctoral thesis, University of Westminster. http:// westminsterresearch.wmin. ac.uk/19996/.

Alireza, Fakhari \& Ebrahemi, Leila (2013) The Global Governance of Islam in Quran. Jurnal Mashreq-e Mouood Vol 6, Number 24. http://www.sid.ir/En/ Journal/ ViewPaper.aspx?ID=316334.

Ardiansyah, Benny Gunawan, Good Governance dan Infrastruktur, 2017, Jakarta, Kementerian Keuangan. https://www. kemenkeu.go.id/publikasi/artikeldan-opini/good-governance-daninfrastruktur/

Aziz, Amin Abdul (2015) Governance in a Contemporay Islamic Negara, Brunei Darussalam: Institute of Public Studies. http://ips.ubd.edu. bn/sym.st. symposium.islamic. governance.html.

Azmi, Mohammad (2017) The Theological Faces of Islamic Governance, Brunei Darussalam: Institute of Public Studies.

Azram, Mohammad (2012) Principles of Good Governance in Islam, Kuala Lumpur: IIUM Press. http://irep. iium.edu.my/1834/.

Bouzenita, Anke Iman (2012) Early Contributions to the Theory of Islamic Governance: $\square$ Abd alRa $\square$ mān al-Awzā̄ $\square \overline{1}$, Journal of Islamic Studies, Vol. 23, Issue 2. https://doi.org/10.1093/jis/ etso41.

Chee, Yung Mei (2015) Islamic Governance: Strategies for Relevance, Brunei Darussalam: Institute of Public Studies. http://ips.ubd.edu.bn/sym.1st. symposium. islamic.governance. html.

Drechsler, Wolfgang (2013) Three 
paradigms of governance and administration: Chinese, Western and Islamic. https:// akademiai.com/doi/abs/10.1556/ SocEc.35.2013.3.3.

Elghuwel, Mohamed I., Ntim, Collins G., Opong, Kwaku K., Avison, Lynn (2017) Corporate governance, Islamic Governance and earnings management in Oman. Journal of Accounting in Emerging Economies, Vol. 7 Issue: 2, https:// doi.org/10.1108/ JAEE-09-20150064 .

Gigado, Abu Dauda \& Yusha'u, Abubakar Sabo (2017) Influence of Accountability and Transparency on Governance in Islam. International Journal of Academic Research in Business and Social Sciences, Vol. 7, No. 6. http://hrmars. com/hrmars_papers/Influence of_Accountability_and_ Transparency_on_Governance_ in_Islam.pdf.

Hamid, Azmi Abd., Haniff, Mohd Nizal, Othman, Muhammad Rahimi, Aziin, Ahmad Saiful, Salin, Puteh (2011) The Comparison of the Characteristics of The Anglosaxon Governance Model and The islamic Governance of IFIS. Malaysian Accounting Review, Vol. 10 No. 2. file://C:/Users/ACER Downloads/ 228-1-896-1-1020160721\%20(3).pdf.

Iqbal Rao Jabaid \& Mahmood, Tahir (2017) Objectives of Governance: A Comparison of Islamic \& Western Tradition in the Context of Pakistan, Tallinn Univeristy School of Governance, Law and Society. http://www.tlu.ee/en/ School-ofGovernance-Law-and-Society.

Ihsan, Hidayatul \& Ayedh, Abdullah (2015) A Proposed Framework of Islamic Governance for Awqaf, Journal of Islamic Economics,
Banking and Finance, Vol. 11 No. 2, Islamic Science University of Malaysia. https://papers.ssrn. com/sol3/papers.cfm?abstract_ id $=2728408$.

Islam, MN (2012) Understanding good governance in Islam: A conceptual analysis. International Journal of Islamic Thought. http://xeroxtree. com/pdf/bangladesh journal_ of_islamic_thought_vol_1_ no_1_2012.pdf $\#$ page $=53$.

Ismail,MuhammadIssyam, Hasan, Rusni bt, and Alhabshi, Syed Musa (2016) Shariah Governance Framework For Islamic Co-Operatives As An Integral Social Insitution In Malaysia. Intellectual Discourse, Suppl. Special Issue; Kuala Lumpur Vol. 24, https://search.proquest. com/openview/730170 $7 \mathrm{~d} 8 \mathrm{c}$ 3bafef85c73ocb9a65b312/1?pqorigsite $=$ gscholar $\& \mathrm{cbl}=826340$.

Ismail, Noor Azian \& Razak, Shaikh Hamzah Abdul (2014) Shariah Governance Framework Gaps and Issues. International Journal of Financial Economics, Research Academy of Social Sciences, vol. 3(1). https://ideas.repec.org/a/ rss/jnljfe/v3i1p1.html.

Kamaruddin, Zaleha (2010) A Malaysian Perspective on Qur'arnic Governance: Family Autonomy vs State Intervention. Islam and Civilisational Renewal, Vol 2, No. 1. https://search. proquest.com/openview / a $8 \mathrm{dc} 2102507401 \mathrm{f} 7 \mathrm{fof} 3128 \mathrm{a}$ $10030518 / 1$ ?pq-origsite $=$ gscholar $\& \mathrm{cbl}=1156339$.

Khan, Mutedar (2010) Democracy is Indispensable; A Political Philosophy of Islamic Governance, The Roundtable Vol. 9 Iss. 2. http:// works.bepress.com/ muqtedar_ khan/17/.

Malik, Maszlee (2011) Constructing the 
Architectonics and Formulating the Articulation of Islamic Governance: A Discursive Attempt in Islamic Epistemology. Theses, Durham University. http://etheses.dur. ac.uk/832/

(2017) Foundations of Islamic Governance: A Southeast Asian Perspective, London: Routledge. https://www.routledge. com/ Foundations-of-IslamicGovernance-A-Southeast-AsianPerspective/Malik/p/book/ 9781138219748.

Malkawi B. \& Sonn T. (2011) Ibn Taymiyya on Islamic Governance. In: Afsaruddin A. (eds) Islam, the State, and Political Authority. Middle East Today. Palgrave Macmillan, New York. https:// link.springer.com/chapter/10. 1057/9781137002020_7.

Minhas, Imran (2012) Shari'ah Governance Model and Its Four Basic Pillars. Islamic Finance News Malaysia Published by Red Money Publication. https://ssrn. com/abstract $=2153106$.

Moten, Abdul Rashid (2017) Al-Siyasah al-Shar'iyah: Good Governance in Islam, Palgrave Macmillan. https:// link.springer.com/chapter/10. 1007/ 978-3-319-57873-6_4.

Muneeza, Aishath (2014) Shari'ah Governance Applicable to Islamic Banks in Malaysia: Effect of Islamic Financial Services Act 2013. Contemporary Studies in Economic and Financial Analysis, Volume 95, Emerald Group Publishing Limited. https://www.emeraldinsight. com/doi/abs/10.1108/ S15693759\%282014\% 290000095010.

MUI (2007) Keputusan Fatwa MUI No. 7/Munas VII/MUI/11/2005 tentang Pluralisme, Liberalisme, dan Sekularisme Agama, Jakarta: Majelis Ulama Indonesia.
Naqvi, Imran Haider, Azis, Shazia, Zaidi, Syed Abbas \& Rehman, Kashifur (2011) The model of good governance in Islam. African Journal of Business Management Vol. 5, 27. http://www.academicjournals.org/ AJBM.

Naser, Abdul Monem (2017) Islam, People and Governance, Beirut: Dar-Al-Kotob Al-Ilmiyah. https:// books.google.co.id/books?id $=$ ox 5 LDwAAQBAJ \&pg $=$ PA $1 \&$ $\operatorname{lpg}=\mathrm{PA} 1 \& \mathrm{dq}=\mathrm{Islamic}+\mathrm{Gover}-$ nance\&source $=$ bl\&ots $=41 \mathrm{~W} \_$GR wAeU\&sig $=$ XCVjZsbhb51VbRUZzslsot3CH9U\&hl=en\&sa $=\mathrm{X}-$ \&ved=oahUKEwjj4bq28NbbAhWGTXoKHVvOAUY4UBDoAQg4MAI\#v=onepage\&q=Islamic\%20 Governance\&f $=$ false.

Obid, Siti Normala Sheikh \& Naysar, Babak (2014) Toward a comprehensive theoretical framework for Shariah governance in Islamic financial institutions. Springer International Publishing AG. https:// link.springer.com/article/10. 1057/ fsm.2014.26.

Ozkan, Necmetin (2011) Principles of Islam for information technology governance. International Conference on Research and Innovation in Information Systems. https:// ieeexplore.ieee.org/search/ searchresult.jsp?searchWithin $=\%$ 22Authors\%22:.QT.Necmettin\%20 Ozkan.QT.\&newsearch=true.

Rauf, Imam Feisal Abdul (2015a) Characteristics of Islamic Governance: The Scholar Consensus, Springer International Publishing AG. https://link. springer.com/chapter/10.1057/9781137446824_4.

(2015b) Human Rights and Islamic Governance, Springer International Publishing AG. https://link.springer.com/chapter/10.1057/9781137446824_9 
Rozan, Mohd (2017) The Evaluation of Islamic Governance, Brunei Darussalam: Institute of Public Studies, http://ips.ubd.edu.bn/sym.3nd. symposium.islamic. governance. html.

Salim, Mohammad Rizal, Kunhibava, Sherin and H'an, Lim (2013) Shariah Governance and Corporate Governance: A Malaysian Case Study. The Law Review, https://ssrn.com/ abstract=2499354 or http://dx.doi. org/10.2139/ssrn. 2499354.

Setyowati, Ro'fah, Abubakar, Lastuti \& Rodiah, Nunung (2017) Sharia Governance on Islamic Banking: Spiritual Rights Perspective on Consumer Protection in Indonesia, Diponegoro Law Review, Volume 02, Number 01. file://C:/Users/ ACER/Downloads/15336-37323-1PB.pdf.

Shaharuddin, A (2011) Shariah Governance of Malaysian Islamic Banking Institutions, Jurnal Ekonom 14 (2). https://scholar.google.co.id/ citations? user $=2$ RvBU7UAAAA$\mathrm{J} \& \mathrm{hl}=$ en\&oi=sra.

Uddin, Md Akther (2015) Governance from Islamic economic perspective: A Shari'ah governance framework. the Munich University Library in Germany. https:// mpra.ub.unimuenchen.de/67695/.

UNESCAP (2009) What Is Good Governance?, Bangkok: Poverty Reduction Section United Nations Economic and Social Commission for Asia and the Pacific. www.unescap. org/resources/what-good-governance.

Welsh, Bridget (2011) New Islamic Governance: The PAS and PKS Evolution. Paper presented at the Association for Asian Studies (AAS)-International Convention of Asia Scholars (ICAS) Joint Conference, Honolulu, HI. http:// ink.library. smu.edu.sg/soss_research/991/. 